\title{
CLEO - pracoviště historické sociologie, nebo sociologizující historiografie?
}

\author{
JIŘÍ MATĚJČEK*
}

\section{CLEO - Research Center of Historical Sociology or Sociological Historiography?}

\begin{abstract}
The article contains the history of the research center since 1980, the main results (social history of the Czech Lands in the $19^{\text {th }}$ century and the development of patterns in the $19^{\text {th }}$ and $20^{\text {th }}$ centuries) and a short information about theory and methods of the "new" social history of the Czech Lands influenced by sociology, social psychology and economy.
\end{abstract}

Keywords: history of research center, social history - Czech Lands $-19^{\text {th }}$ and $20^{\text {th }}$ centuries

\section{Úvod}

Druhá varianta titulu by byla asi přece jen příliš extravagantní a žádný název stejně nemůže vystihnout současné - a vlastně už dlouhodobé - prolínání jednotlivých disciplin sociálních (nebo humanitních?) věd. Matoucí je však i jméno Cleo - ne zkratka Kleopatry, ale trochu zlidovělé jméno múzy Cleió, které mělo současně upozornit na směřování naší práce ke cliometrii (matematizaci) - jak se zdá, dnes z historiografie vytlačené postmodernistickou básnivostí a neurčitostí (dokonce Zygmunt Bauman v Tekuté modernitě). Př́spěvkem k jisté bufonádě, reagující na smrtelnou vážnost našich společenských věd $\mathrm{z}$ doby marxistického pozitivismu i jeho pomalého soumraku (ale asi ne úplného zániku) v 90. letech je i humoristické „logo“ pracoviště.

Ale dál nejprve (jen trochu vážněji) pamětnické vyprávění, dost symptomatické pro naše společenské vědy a snad i poučné pro naše mladé neomarxisty, kteří, podobně jako západoevropští levicoví intelektuálové, nemají zkušenost s „reálným socialismem“ (ostatně pamět lidstva je všude velice krátká). Náš dvoučlenný tým spř́izněný nápady (dál však ukážeme, že jsme vždy nepracovali jen dva) vznikl na začátku 80. let 20. století ve Slezském ústavu ČSAV v Opavě, kde se jeho „hezká“ polovina dlouhodobě zabývala sociálními dějinami českých zemí a průmyslových oblastí v době industrializace, ta „stará“ potom hlavně hospodářskými dějinami a historickou demografií téhož období. Od poloviny 80 . let jsme pak společně začali relativně systematicky zpracovávat sociální dějiny českých zemí v 19. a 20. století - nejdřív formou rozsáhlé zprávy za období 1945-1989, která, i na základě srovnání se „západoněmeckou“ a polskou sociální historiografií, ukázala svému rozsahu úměrné mezery v poznatcích. ${ }^{1}$ Protože však měla být publikována už v roce 1988, nemohla upozornit na vady vzniklé ideologickým řízením společenských věd stranickými tajemníky a cenzurou; sociální dějiny byly jen jakousi neurčitou silně opomíjenou spojkou mezi „postavením dělnictva“, líčeným podle vzoru

\footnotetext{
* PhDr. Jiří Matějček, DrSc., CLEO - pracoviště historické sociologie, 28401 Kutná Hora, Pod Valy 139.

1 Machačová, Jana - Matějček, Jiří. [1992]. Stav výzkumu sociálního vývoje českých zemí v období 1781-1914. In Studie k sociálním dějinám 19. století, I. Opava: Slezský ústav ČSAV, s. 9-166.
} 
„klasika“ Jürgena Kuczynského, a politikou - „třídním bojem“. Skutečné vlastnosti, pozice a cíle „dělnické tř̌́dy“ a dalších sociálních skupin bylo sice možné sledovat, ale ne výsledky protiřečící marxistickým dogmatům uveřejnit, a to nejspíš ani jako interní tisk, i když se v 80. letech prostředí společenských věd dost zliberalizovalo.

Situace se samožrejmě změnila po nečekaném převratu v roce 1989. Mohli jsme otisknout dvě naše monografie vzniklé už za socialismu. ${ }^{2} \mathrm{~V}$ první jsou statistickou analýzou vyvráceny marxistické báchorky o stávkách, ve druhé je rozsáhlá kapitola o skutečné subkultuře moderního hornictva. Problematika dělnictva, do poloviny 20. století nejpočetnější skupiny obyvatelstva, byla po roce 1989 v české historiografii na dvacet let skoro opuštěna a vrací se až nyní, zdá se, že často ve formě neomarxistického přikrašlování. Hned nato jsme uveřejnili obsáhlou zásadní studii o reálných mzdách dělnictva ve druhé polovině 19. století, také napsanou ještě za socialismu a uvádějící na pravou míru agitační zkazky, že „dělnictvo žilo v bídě a otroctví“. ${ }^{3}$ Upozorňujeme zde na tyto práce ani ne tak proto, abychom se pochlubili, ale hlavně proto, že oficiální historiografie („přední historici“) tyto zásadní výsledky dodnes nezná a nepoužívá. Čtou jen to, co píší jejich známí a v poslední době a co se píše v cizině, a občas se stále objevuje tvrzení, že „dělnictvo žilo v bídě“. (Přitom už v 60. letech přestali chytřejší „přední historici“ potichu psát o „zbídačování proletariátu“; pro české země 19. a 20. století to úplně odporuje skutečnosti. Jde ovšem i o to, kdo byl v dobové terminologii - např́klad na konci 18. a v 19. století - „dělník“, i o to, co je „bída“, podle nás neuspokojování ani základních biologických potřeb.)

Se vznikem grantových agentur Akademie věd České republiky a Grantové agentury České republiky (GA ČR) se objevila možnost širšího výzkumu s angažováním většího kolektivu externích spolupracovníků, kterých bylo postupně asi dvacet. Jejich i naše vlastní studie jsme publikovali v dost oceňovaných a už dávno rozebraných sbornících Studie k sociálním dějinám 19. století (1992-1997 osm svazků) a Studie k sociálním dějinám (1998-2004 dvanáct svazků; v obou řadách měly jednotlivé svazky obvykle kolem 250 stran, takže celkem vyšlo asi pět tisíc stran většinou dost kvalitních textů). Studie potom zanikly pro nezájem komisí GA ČR, která dál náš výzkum nepodporovala. ${ }^{4}$ Ani s grantovou podporou - ve volné neformální organizaci bez subordinace a dostatečného finančního zajištění spolupracovníků - se však nedalo dosáhnout zamýšlených výsledků;

2 Machačová, Jana. [1990]. Mzdové a stávkové hnutí dělnictva v průmyslových oblastech českých zemí 1848-1914. Opava: Slezský ústav ČSAV. Matějček, Jiří. [1990]. Formování sociální skupiny horníků uhlí v českých zemích (1800-1914). Opava: Slezský ústav ČSAV.

3 Machačová, Jana. [1991]. Tendence vývoje mezd dělnictva 1848-1948. Srovnání takzvaných starých a nových průmyslových oblastí. In. K hospodářským a sociálním dějinám 19. a 20. století, I. Opava: Slezský ústav ČSAV, s. 145-319. Stejně rozsáhlá studie vyšla už dříve zásluhou pražských osvícenců (redaktorů dr. F. Dudka, CSc., dr. M. Hlavačky, CSC. a ředitele Ústavu československých a světových dějin profesora Purše): Matějček, Jiří. [1986]. Reálné mzdy horníků uhelných doli̊ v českých zemích do roku 1914. In. Hospodářrsé dějiny - Economic History, 14, 1986, s. 217-324. Podobnou studii jsme publikovali i o hutnících železa. Studie Machačová, Jana - Matějček, Jiří. [1991-1992]. Nástin vývoje textilní výroby v českých zemích 1781-1848. Opava: Slezský ústav obsahuje ve třetím díle údaje o životní úrovni a subkultuře textilních výrobců.

4 Empiricky ověřeným faktem - nejen naší zkušeností - je, že grantové agentury jsou vzájemně podpůrné spolky zástupců pracovišt', kde je potřeba mít dobré známé, nebo osoby, které je možné si zavázat nějakými službami. Kromě toho se zdá, jako by znovu přicházel do módy ne základní výzkum, ale témata, po nichž je „společenská poptávka“, jako tomu bylo za socialismu, tj. výzkumy užitečné pro politiku. 
zásadní metodicky účelné faktograficko-syntetizační studie jsme si stejně museli napsat sami. To snad ustupuje se současnou lepší organizací grantových systémů.

Mezitím už v roce 1994 vznikla po „zeštíhlení“ ČSAV (AV ČR) Cleo jako soukromé živnostenské pracoviště, aby bylo možné žádat o granty, když se všech zbylých osm „zeštíhlených“ badatelů Slezského ústavu mělo věnovat výhradně „cikánské otázce“. Po čtvrt roce se tím už nezabýval nikdo - jen my dva „hloupí poctivci““.

Celá činnost zpočátku týmu a pak i pracoviště byla, jak už jsme naznačili, zaměřena na zpracování syntézy sociálního vývoje českých zemí, nejprve v 19. století, kdy probíhala zásadní „modernizace“ sociálního i ekonomického a obecně kulturního systému, jejíž základní příčinou i podmínkou byla industrializace včetně přechodu mas obyvatelstva ze zemědělství do průmyslové výroby a z velké části i do měst. Její důsledky registrujeme ještě dnes. Postupovali jsme standardním způsobem od sociální stratifikace, jež se měnila hlavně právě vlivem industrializace, ke vzorům chování a prožívání (obecné kultuře) a $\mathrm{k}$ př́islušným procesům. ${ }^{6}$ Tak vznikla řada našich většinou dost rozsáhlých studií, zaplňujících ještě rozsáhlejší mezery a mimo jiné rektifikujících různé mýty, jakož i dílčí studie našich externích spolupracovníků s nejrůznější relevantní tematikou. Na základě celého tohoto souboru vznikla pak syntetizující monografie, ${ }^{7}$ která začala být brzy používána jako neoficiální učebnice na některých vysokých školách. Náš výzkum pak pokračoval - od roku 2004 bez externích spolupracovníků - podrobným studiem vzorů chování a prožívání. Jako výsledek vznikla monografie navazující na Nástin vývoje textilní výroby zčásti koncipovaná jako další učebnice. ${ }^{8}$ Mezitím vyšel sborník našich prací, aspoň částečně zaplňující obrovskou mezeru z dob socialismu, ${ }^{9}$ a už dřív monografie, která navázala na starší studium dějin první republiky a zčásti nás přivedla $\mathrm{k}$ jeho dnešnímu pokračování, které zasahuje i do dějin období socialismu. ${ }^{10}$ Od roku 2009 jsme přešli k tématice dotvářející „triádu“ sociální stratifikace $\rightarrow$ vzory chování (obecná kultura) $\rightarrow$ existence. K poslednímu článku triády jsme zatím napsali jen úvodní studii. ${ }^{11}$ Dosud oba členové týmu publikovali společně a individuálně dohromady asi 300 odborných prací - monografií, sborníkových studií a časopiseckých článků. Dost zásadní nám připadají dva krátké články shrnující problematiku sociálního vývoje za socialismu. ${ }^{12}$

5 Machačová, Jana. [1994]. Vývoj zákonodárství a Cikáni v českých zemích 1848-1918. In. Slezský sborník 1994, s. 12-21.

6 V české historiografii se většinou stále mluví a píše o „mentalitách“, ačkoli je nikdo nedefinoval. Zdá se, že se o nich píše (pokud se o tom vủbec píše), podobně jako ve Francii a v Německu, nestrukturovaně, dohromady o všem a o ničem.

7 Machačová, Jana - Matějček, Jiří. [2002]. Nástin sociálního vývoje českých zemí 1781-1914. Opava: Slezský ústav AV ČR a Praha: Karolinum 2010.

8 Machačová, Jana - Matějček, Jiří. [2008]. Problémy obecné kultury v českých zemích 1781-1989. Opava: Slezský ústav SZM.

9 Machačová, Jana - Matějček, Jiří. [2002]. O středních vrstuách v českých zemích 1750-1950. Opava: Slezský ústav AV ČR.

10 Machačová, Jana - Matějček, Jiří. [1999]. Sociální pozice národnostních menšin v českých zemích 1918-1938. Opava: Slezský ústav AV ČR. Machačová, Jana - Matějček, Jiří. První republika trochu jinak: kontinuita a diskontinuita vzorů chování a prožívání (patterns). In. Jan Němeček a kol. [2010]. Československo a krize demokracie ve střední Evropě ve 30. a 40. letech XX. století. Hledání východisek. Praha: Historický ústav, s. 357-371.

11 Machačová, Jana - Matějček, Jiří: Existence v českých zemích v 19. a 20. století... Kvalita života a kvalita populace. Moderní dějiny 18, 2010, s. 35-75.

12 Machačová, Jana - Matějček, Jiř́i. [2004]. Co se zločiny komunismu? In. Kárník, Zdeněk (ed.) Věstník grantu KSČ a radikální socialismus v Československu 1918-1989, č. 10. Praha: Ústav pro soudobé 
Tým a pak pracoviště se však nevěnovaly jen výzkumu, ale i jeho organizaci v širším měřítku. V roce 1997 jsme uspořádali kolokvium o horních vrstvách společnosti českých zemí v 19. století, ${ }^{13}$ v roce 2000 ve spolupráci s Ústavem hospodářských a sociálních dějin FF UK konferenci o sociálních dějinách českých zemí v 18., 19. a 20. století (Studie 6 z roku 2001), v roce 2001 ve spolupráci s odborovým archivem ČMKOS konferenci o metodologii sociální historiografie (Studie 8 z roku 2001), v roce 2002 ve spolupráci s Fakultou humanitních studií UK konferenci o středních vrstvách (Studie 10 a 10/2 z roku 2002) a v roce 2004, opět ve spolupráci s FHS, konferenci „Vývoj obecné kultury, kultivace a dekultivace společnosti českých zemí 1800-2000“ (Studie 11 z roku 2004).

Tým a pracoviště spolupracovaly s vysokoškolskými ústavy a katedrami (Filozofické fakulty Univerzity Karlovy, Fakulty humanitních studií Univerzity Karlovy, Univerzity Pardubice, Masarykovy univerzity, Ostravské univerzity, Univerzity Palackého v Olomouci, Univerzity Jana Evangelisty Purkyně v Ústí nad Labem, Slezské univerzity v Opavě), dále s Collegiem Carolinem a v poslední době také s Historickým ústavem AV ČR - vždy hlavně vzájemnou účastí na konferencích a publikováním v jejich i našich sbornících, mj. v Prager Wirtschafts- und Sozialhistorische Mitteilungen (WISOHIM).

Kvůli organizačním obtížím jsme mohli jen dva semestry přednášet historickou sociologii na Filozofické fakultě Univerzity Karlovy a Jana Machačová pak vedla dva semestry seminář sociálních dějin na Slezské univerzitě v Opavě. Kromě naší společné práce na edicích Studií (vycházely jako ročenka, někdy však i dvakrát nebo třikrát za rok) redigovala Jana Machačová od začátku 70. let do roku 2009 Slezský sborník, který byl kvůli neštastnému tradičnímu názvu snad považován za nějaký regionální vlastivědný časopis, a proto málo sledován, ale byl od začátků až do roku 2009 (107 ročníků) věnován historiografii, od 60. let nejen Slezska, ale zvlášt hospodářským a sociálním dějinám českých zemí v 19. a 20. století, dějinám průmyslových oblastí a historické demografii a za socialismu. Byl v mnichovské Bohemii pro svou věcnost hodnocen často výše než ideologický Československý časopis historický. Společně i individuálně jsme tam uveřejnili množství studií, zpráv, recenzí a glos, dosti často se zásadní tematikou. Systematicky jsme publikovali přehledy stavu výzkumu, jejichž seznam snad může být užitečný. ${ }^{14}$

Severský sociolog Stein Rokkan kdysi napsal: „Sociology is history with the hard work left out, history is sociology with the brain left out.“ To mohl jistě napsat jen sociolog, ještě dost drzý; mezi ortodoxními historiky vzbudila citace pohoršení. O vztazích historiografie a sociologie se psalo odedávna, snad od Comtových časů, dokonce i v Sovětském svazu několik let po Stalinově smrti, když tam sociologie náhle přišla do módy.

dějiny AV ČR, s. 82-88. Machačová, Jana - Matějček, Jiří. [2005]. Pět idejí lidových vrstev. K zapomenutému projektu profesora Grosse. In. Kárník, Zdeněk (ed.) Věstník grantu KSČ a radikální socialismus v Československu 1918-1989, č. 12. Praha: Ústav pro soudobé dějiny AV ČR, s. 60-66. Oba články jsou otištěny i na konci publikace Machačová, Jana - Matějček, Jiří. [2008]. Problémy obecné kultury $v$ českých zemích 1781-1989. Opava: Slezský ústav SZM.

13 Předem připravené referáty byly publikovány ve Studiích k sociálním dějinám 3 v roce 1999.

14 Vedle už citované zprávy za léta 1945-1989 zprávu za léta 1990-2000 (ČČH 2001), zprávu o stavu výzkumu stávek a dělnického hnutí (Studie 2 z roku 1998 - zároveň stručné dějiny dělnického hnutí u nás v 19. století), zprávu o stavu výzkumu sociálního vývoje českých zemí - výsledky po roce 2000 (Česko-slovenská historická ročenka 2007) a spolu s D. Musilovou a N. Pavelčíkovou zprávu o stavu výzkumu sociálního vývoje za první republiky a za nacistické okupace (Reflexe dějin Československa 1918-1948 v historiografii na počátku 3. tisíciletí. Ed. J. Němeček. Praha, HÚ AV ČR 2008.) Všechny zprávy byly vždy s určitým zpožděním publikovány v němčině ve WISOHIMu. 
Historiografie měla většinou připravovat „faktografický materiál“ pro sociologická zobecnění, ale př́liš se neuvažovalo o tom, která fakta, kde a jak sledovat. Tak se stávalo a stává, že „obvyklý historik“ se bez rozmyslu vrhá rovnou na „fakta“; zdá se však, že rozumné projekty se ted’ už připravují sofistikovaněji, aspoň na některých pracovištích, a že se snad i u nás pomalu (v centrech pokroku) začíná praktikovat simultánní vysokoškolské studium historiografie a sociologie, př́ípadně dalších relevantních disciplin, jak je to už docela běžné v zahraničí.

Motivací našeho týmu bylo od začátku odlišit se od popisné faktografické nebo narativní historiografie líčící „události“ a od pragmatických výkladů sledujících jen bezprostřední „příčiny“ bez hlubších souvislostí. Druhou motivací byl odklon od pozitivizmu z konce 19. století, který ve zvlášt zdegenerovaných formách hromaděním co největšího množství dílčích studií s nejrůznější tematikou zvolenou hlava nehlava (často konjunkturálně: náboženská problematika ke konci 19. století, agrární dějiny za první republiky, dělnické hnutí, často mimořádně diletantsky, za komunistů) doufal obsáhnout „dějiny“. Naším cílem byla syntetizace a co možná všestranný výklad, k němuž měly dát „referenční rámec" moderní sociální vědy: obecná sociologie, sociální psychologie, sociální a kulturní i filozofická antropologie (za „historickou antropologii“ se však u nás dnes pokládá kdeco) a „skutečná“, ne vulgárně marxistická ekonomie.

V úvodu k monografii o Problémech jsme však upozornili, že našim výzkumům chybí hlubší obecně filozofický základ. V 80. a 90. letech jsme se snažili o uplatnění složitějších statistických metod - nad pouhou u nás obecně užívanou tabelaci dat. ${ }^{15} \mathrm{~V}$ té době jsme usilovali rovněž o další zdokonalování metodologie: komplexitu, systemizaci a formalizaci výzkumů a jednotlivých postupů, ale praktické aplikace zůstaly spíš v náznacích (ve Studiúch k sociálním dějinám 19. století 4 a 5) - museli jsme zaplňovat mezery ve faktografii pro syntetické výzkumy a soustředovali jsme se spíš na propracovávání fungující metodiky práce s takzvanými vyprávěcími prameny nebo s „prameny osobní povahy“, které se staly naší hlavní pomůckou při studiu vzorů chování a prožívání. ${ }^{16}$ Vznikly tak dílčí př́ípadové studie a pilotáže, pak rozsáhlejší syntetizační studie a nakonec uvedené syntetické monografie.

Naše motivace vždy směřovaly proti teoretické a metodické neujasněnosti a bezduchému tápání při př́pravě výzkumů. K objasnění se musíme na chvíli vrátit k pamětnickému vyprávění, také dnes snad zajímavému (i poučnému).

Přibližně od roku 1970 zavládl na provinčním pracovišti diletantismus, nemožný v metropoli, kde byl celkem úspěšně sabotován „Jednotný program společenských věd“,

15 Dobu - snad i dnešní - předběhla skripta FF UK, která napsali Jan Havránek a Josef Petráň: Statistika pro historiky z padesátých let. Dnes už je podobných příruček množství, ale víme jen o zahraničních. U nás existují spíš proklamace a vedle některých našich studií použil složitějších statistických metod a matematizace jen náš spolupracovník exulant Tomáš Weiser při studiu sociální diferenciace pomocí analýzy shluků (Studie 10). Pro matematické zpracování historiografických témat jsou zatím zralé spíš jen dílčí problémy: viz Weiser, nebo naše Machačová, Jana - Matějček, Jiří. [1985]. Skladba osádky dolu Johann [Koh-i-noor] v severočeském hnědouhelném revíru v letech 1893-1895. Statistická analýza. In. Ústecký sborník historický 1985, s. 263-307. Pokusy „matematizovat“ historiografii jsou dost staré. Skoro komicky dopadl Reshewského pokus ze začátku 20. století modelovat makrosociální procesy soustavou primitivních lineárních rovnic, odlišných však od lineárního programování, jak to mnohem později učinil Fogel při studiu významu vzniku železnic v USA

16 Ve Studiích k sociálním dějinám 19. století 2 z roku 1992 jsme vyhodnotili možnosti využití české a česko-německé realistické beletrie z poslední čtvrtiny 19. století jako pramene sociální historiografie. 
vymyšlený na ÚV KSČ, který měl historiografii, sociologii, etnologii, případně další vědy přeměnit na agitační média propagující dokonalost komunismu. (Psychologové na pražské univerzitě, vedení profesorem Jaromírem Janouškem, se prohlásili za přírodovědce a byli ponecháni „buržoaznímu zahnívání“.) „Ředitelem vědy“ se v severomoravském kraji stal ideologický tajemník KV KSČ, původně zběhlý horník. O něco později přišel se sloganem, zřejmě odposlouchaným „na nejvyšších místech“: „Co bylo před rokem 1945, nás nezajímá. “ Podle toho se v roce 1973 připravoval plán na pětiletku pro dvacet vědeckých pracovníků. Ředitel za asistence stranického předsedy jej vymysleli za deset minut a oznámili „lidu“: „Ty (průmyslové) oblasti popíšeme, a pak se to nějak porovná.“

Jsou to všechno už jen anekdotické historky, ale ukazují, kam až může dospět údajně kulturní národ i jeho věda za určitých poměrů. Téma pro Ústav pro studium totalitních režimů s jeho (aspoň podle televize) fantastickými miliony ze státních peněz stále snad hlavně na popisné studium „perzekucí“ - nacistických a komunistických: jak nám pořád někdo ubližoval.

Jak jsme už naznačili, abstraktnější společenskovědní discipliny pro nás byly spíš „pomocnými vědami“ $\mathrm{k}$ modernizaci metodologie syntetického výkladu dějin společnosti v českých zemích uplynulých dvou století, rozděleného do zmíněné „triády“ postupu, v němž se stále víc orientujeme na dlouhodobé vývojové tendence - jimiž se empirická sociologie př́liš nezabývá, př́padně na invarianty a stabilitu. Tak se do našich prací dostaly pojmy v tradiční historiografii málo užívané nebo úplně neznámé. Např́íklad (v neuspořádaném výběru) telegraficky: sociální skupiny, sociální pozice, status - prestiž, sociální uznání, sociální stereotypy, motivace, potřeby, hodnoty, cíle, zaměření, energie, snaha, sklon k učení, self-image, vzory chování a prožívání (se vzory chování se už přece jen občas setkáváme u mladších badatelů), internalizace, socializace, životní pocit, kvalita života, kvalita populace, inovace, difúze inovací, informační pole, emoce (z historie vymýcené snad 200 let), postoje, skupinové postoje, osobnost, modální osobnost, skupinová zkušenost, sociální kontrola, kultura, obecná kultura, kultivace, dekultivace, antropologické konstanty, zisk (důchod, revenue, o němž marxistická hospodářská historiografie nechtěla nic vědět - ostatně jediným školeným ekonomem mezi hospodářskými historiky byl Václav Průcha; nyní též Antonie Doležalová a snad i někteří mladí); stejně tak se nesmělo za socialismu psát ani mluvit o elitách.

Musíme přiznat, že systematiku studia sociálního vývoje (mimo jiné standardní „trajektorii chování“, postupující od emocionálního uspokojení jako konečného cíle až ke změnám stavů společnosti, která se nám stala jednou z hlavních pomůcek analýzy) jsme si vypracovali na základě starodávného a napadaného (zvlášt teoretiky konfliktu) strukturálního funkcionalismu, jehož jedním zdrojem byla vcelku uznávaná sociální teorie Maxe Webera, dalším potom etnologické a antropologické výzkumy z první poloviny 20. století, a který se promítá i do sociální teorie Pierra Bourdieu, jenž byl ve velmi nedávné minulosti a snad ještě je guru části mladých historiků. (Vedle Richarda van Dülmena s jeho strašidly, čarodějnicemi a sexuálními deviacemi - spíš výběrem jednotlivostí a zajímavostí, které jistě měly sociální význam, ale většinou málo spojený se základními faktory existence, sociálními vztahy a interakcemi. Jedná se jistě o reakci na „strukturní dějiny“.) Jiří Pešek před několika lety upozornil na zaklínání se historiků citáty z Marxe a Engelse za socialismu, které v nedávné době nahradili Foucault a Bourdieu. Dnes už zřejmě platí jiné idoly, ale „snobisticky systémově“ se citují i nesmysly, jen když pocházejí 
od nějaké zahraniční autority. ${ }^{17}$ Teorie a postupy se nejčastěji přejímají z Německa a Rakouska, ale nemusí být vždy adekvátní - ani tam nejsou samí geniové, jak se u nás často myslí - i když jsou samozřejmě inovace i nám blízké - např́íklad studium významu emocí, nyní silný zájem zvlášt historických antropologů, a emocionálního uspokojení - „smyslu dějin“.

Nastínili jsme celkový program pracoviště, z něhož byl realizován výzkum sociální stratifikace a mobility a vývoje vzorů chování a prožívání v posledních dvou stoletích - obojí však jen v hrubém nástinu. Zbývá třetí část „triády“, existence, kde je zatím jen zhruba naznačena „operacionalizace“ jako soubor významných žádoucích témat. Fatální vadou ovšem je, že skoro úplně chybí „skutečné“ sociální dějiny období socialismu a už vůbec se nedá mluvit o nějakém systematickém studiu vzorů chování a prožívání pro tuto dobu. ${ }^{18}$ Zatím se zkoumaly hlavně „zločiny komunismu“ v jejich vnějškově kriminálních formách - jež samožrejmě nebyly to hlavní - a dosti podrobně vývoj socialistického hospodářství, ale jediný nadějný náběh ke studiu vzorů chování (duchovního základu „všeho“) se zvrtl v podstatě ve sledování sociální politiky komunistického státu, jak se o tom psalo dř́ve. ${ }^{19}$

Ale jak jsme další výzkum „zoperacionalizovali“? Za základní úkol jsme prohlásili studium vývoje kvality populace - jejího „existenčního vybavení“ faktory úspěšné činnosti: motivacemi, energií, inteligencí, hmotnými zdroji a znalostmi správných způsobů jednání, vzorů chování, know-how. Znalosti souborů příslušných vlastností pozic a vzorů chování jsme soustředili do „pasportů“ jednotlivých sociálních skupin; ty bude tedy potřeba dál prohlubovat a zpřesňovat. Zatím chybí zvlášt závažný „paspart“ vedoucích vrstev společnosti po vytlačení šlechty z vedoucích sociálních funkcí. Jen velmi špatně jsou popsány vlastnosti elit „kapitalistické éry“, mimo jiné za první republiky a tím méně za socialismu. ${ }^{20}$

Jedním z významných témat se nám zdá být např́iklad i sledování vývoje a minulé i současné rozšířenosti různých typů „myšlení“ od jeho „předlogických“ forem, zřejmě ještě dost často frekventovaných v závislosti na způsobu existence. Samotné znalosti způsobů existence, zvlášt „sublokální“ (se zájmem jen o vlastní osobu, rodinu a nejbližší okolí) a „lokální“ v 19. a 20. století frekventované u živnostníků nebo sedláků, jistě vyžadují prohlubování, stejně jako jejich souvislost právě s formami „myšlení“ i s postoji. Zásadní význam pro vývoj kvality populace v současnosti i kvality života u nás zřejmě měl vývoj vztahů mezi kultivací profesní (sféry odborných, pracovních znalostí), kultivací sociální (vztahů mezi jednotlivci a skupinami ve veřejné i soukromé sféře) a kultivací osobnostní, která mohla vytvářet takzvané pozitivní (benigně usilující) nebo harmonické

17 V posledním ČčH z roku 2009 se cituje definice „práce“, kterou zahraniční hvězdná autorita zřejmě opsala z nějaké druhořadé učebnice ekonomie, podle níž nepracuje samozásobitelský zemědělec ani zahrádkář, pěstující mrkev pro rodinu: nevyrábějí zboží.

18 Matějček, Jiří. [2004]. „Mentality“ v Československu za socialismu a v době jeho přípravy a česká historiografie z let 1990-2000. In. Slezský sborník 2004, s. 106-121.

19 Deyl, Zdeněk. [1985]. Sociální vývoj Československa. Praha. Za nadějný náběh považujeme Kalinová, Lenka. [2004]. Východiska, očekáváni a realita poválečné doby. Československo v roce 1945. Praha. Zaměření na vzory chování bylo však opuštěno v další autorčině knize: Kalinová, Lenka. [2007]. Společenské proměny v době socialistického experimentu. K sociálním dějinám v letech 1945-1969. Praha.

20 Pro první republiku existuje stručná značně emocionální charakteristika Inocence Arnošta Bláhy. František Zich se zabýval vlastnostmi komunistických elit z doby socialismu, ale jen středostavovských, ve Studiúch 10/2. O vládnoucích komunistických elitách píše Jiří Pernes. 
(„vyvážené“) osobnosti, obojí s významem pro sociální i profesní kultivaci v menších nebo větších okruzích působnosti.

A pak ty dlouhodobé vývojové tendence „všeho“! Tak bychom mohli pokračovat dost dlouho, zásadní chyba však je, že badatelů zaměřených na sociální vývoj, zvlášt dlouhodobý, a na zobecňující výzkum je v malé (a chudé) zemi málo - „nejsou lidi“.

PhDr. Jiři Matějček, DrSc. (1930) - pracoviště historické sociologie CLEO v Kutné Hoře dlouhodobě spolupracuje s Janou Machačovou ze Slezského ústavu v Opavě. Zabývá se procesy modernizace a dlouhodobými změnami vzorců chováni. Mezi hlavní témata patři vývoj společnosti Českých zemi 19. století v kontextu Evropy, dále sociální stratifikace, funkčni a profesni skupiny. V posledni době publikoval společně s Janou Machačovou Nástin sociálního vývoje českých zemí 1781-1914 (Praha: Karolinum 2010, 2. vyd.). 